\title{
Pengaruh pH terhadap Produksi Antibakteri oleh Bakteri Asam Laktat dari Usus Itik
}

\section{Effect of pH on Production Antibacterial by Lactic Acid Bacteria From Gut Duck}

\author{
Rudy Sutrisna ${ }^{1}$, Christina Nugroho Ekowati ${ }^{2}$, Edelina Sinaga ${ }^{3}$ \\ ${ }^{1}$ Dosen Jurusan Peternakan Fakultas Pertanian Universitas Lampung \\ ${ }^{2}$ Dosen Jurusan Biologi FMIPA Universitas Lampung, Bandar Lampung, Indonesia \\ ${ }^{3}$ Mahasiswa Jurusan Biologi FMIPA, Universitas Lampung, Bandar Lampung, Indonesia \\ Jln. Prof.Dr. Soemantri Brojonegoro No. 1, Bandar Lampung, Lampung, Indonesia, 35145 \\ korespondensi :adelialina@ymail.com
}

\begin{abstract}
This study aimed to determine the effect of $\mathrm{pH}$ on the production of antibacterial by lactic acid bacteria. This study uses a completely randomized design factorial $3 X 5$ ( 3 $X 5$ treatment of bacterial isolates $p H$ ) with three replications. The first factor consisted of $\mathrm{pH} \mathrm{4,} \mathrm{pH} 5, \mathrm{pH} \mathrm{6,pH} \mathrm{7,} \mathrm{pH} 8$, and the second factor that isolates $\mathrm{B2}, \mathrm{B} 7$, $B 8$, whereas the parameters consists of a clear zone. The amount of production is determined by the size of the diameter of antibacterial inhibition zone against Salmonella sp. Differences in the production of antibacterial determined based on the results of analysis of variance. The treatment significantly further test BNT at 5\% level. The results showed that the effect of media $\mathrm{pH}$ test based on the potential for the production of antibacterial effect. The diameter of the largest clear zone produced by B7 isolates at pH 6 was $17.2 \mathrm{~mm}, 17.1 \mathrm{~mm} \mathrm{B8}$ and $B 2$ at pH 7 at $16.7 \mathrm{~mm}$. The smallest diameter of the clear zone produced by $B 8$ at $\mathrm{pH} 4$ was $15.1 \mathrm{~mm}$, B2 at $\mathrm{pH} 6$ there is a clear zone of $12.7 \mathrm{~mm}$ and isolate B7 at pH 5 of $11.5 \mathrm{~mm}$
\end{abstract}

Keywords: Antibacterial, Lactic Acid Bacteria, pH, Salmonella sp, Clear zone

Diterima: 11-08-2015: disetujui 23-10-2015

\section{PENDAHULUAN}

Salah satu sumber bakteri asam laktat (BAL) diperoleh dari usus itik. Pada umumnya, BAL digunakan sebagai probiotik, khususnya genus Lactobacillus dan Bifdobacterium yang merupakan bagian dari flora normal pada saluran pencernaan (Sujaya et al., 2008). Keberadaan BAL mampu bertahan di dalam variasi $\mathrm{pH}$ pada saluran pencernaan itik (Tillman et al., 1989). Pada tembolok itik memiliki $\mathrm{pH}$ sekitar $\mathrm{pH} 6,3, \mathrm{pH}$ di lambung antara $1-2, \mathrm{pH}$ di ileum antara 7 dan $8, \mathrm{pH}$ di proventrikulus $2-4$, dan $\mathrm{pH}$ di ventrikulus 2,6 (Anggorodi, 1984). Bakteri asam laktat mampu memproduksi bakteriosin untuk menghambat atau membunuh bakteri yang bersifat selektif hanya terhadap beberapa strain patogen. Salah satu produksi antibakteri dipengaruhi oleh faktor lingkungan yaitu $\mathrm{pH}$, umur bakteri, waktu inkubasi, suhu dan lain - lain. PH optimum diperlukan untuk produksi antibakteri karena $\mathrm{pH}$ sangat berpengaruh dalam pembentukan bakteriosin optimum pada pH 5 dan 6 
pada media MRS (Mogjani dan Amirnia, 2007). Peningkatan pH sampai pH optimum menghasilkan produksi bakteriosin yang maksimal, sementara itu faktor suhu memiliki dua prngaruh yang bertentangan yaitu meningkatkan produksi bakteriosin tetapi juga bisa membunuh BAL penghasil bakteriosin (Januarsyah, 2007). Produksi antibakteri semakin efektif dalam menghambat pertumbuhan bakteri Salmonella sp. apabila semakin luas/lebar zona hambat yang terbentuk disekitar sumur (Jawet,1996).

Penelitian ini untuk mengetahui pengaruh variasi $\mathrm{pH}$ terhadap produksi antibakteri oleh Bakteri asam laktat. Melalui penelitian ini diharapkan dapat memberikan informasi $\mathrm{pH}$ optimal terhadap produksi antibakteri oleh bakteri asam laktat.

\section{METODE}

Alat-alat yang digunakan dalam penelitian ini antara lain tabung reaksi, tabung anaerobic jar, cawan petri, erlenmeyer, vortex mixer, inkubator dengan suhu $37^{\circ} \mathrm{C}, \mathrm{pH}$ meter. Bahan-bahan yang digunakan pada penelitian ini adalah Nutrient Agar, (NA), MRS Broth, Bacterial Agar, 3 isolat bakteri dari usus itik yaitu B2, B7, dan B8 (koleksi Sutrisna, 2010) yang diremajakan, isolat bakteri uji Salmonella sp. umur 24 jam, larutan buffer fosfat dan sitrat

\section{Pembuatan starter}

Bakteri yang berumur 48 jam diambil sebanyak $1 \mathrm{ml}$ dan dimasukkan ke dalam $9 \mathrm{ml}$ MRS Broth steril, lalu diinkubasi selama 48 jam dalam anaerobic jar

\section{Produksi antibakteri}

Sebanyak 20 ml MRS Broth Steril dengan larutan buffer sitrat untuk membuat $\mathrm{pH} \mathrm{4,} \mathrm{5,} \mathrm{dan}$ pH 6, kemudian dimasukkan $4 \mathrm{ml}$ starter. $20 \mathrm{ml}$ MRS Broth Steril dengan ditambahkan larutan buffer fosfat untuk dibuat $\mathrm{pH} 7$, dan $\mathrm{pH} 8$ lalu diukur dengan $\mathrm{pH}$ meter ,kemudian dimasukkan $4 \mathrm{ml}$ starter dan diinkubasi selama 48 jam.

\section{Preparasi antibakteri}

Sebanyak $5 \mathrm{ml}$ kultur diambil untuk diukur pH sesudah inkubasi 48 jam. Lalu $5 \mathrm{ml}$ kultur diambil dan ditambahkan $\mathrm{NaOH} 1 \mathrm{M}$ dengan menggunakan pipet tetes hingga $\mathrm{pH}$ menjadi $\mathrm{pH} 7$. Kemudian diambil 0,1 ml untuk dimasukkan ke dalam microtube dan di sentrifuge dengan kecepatan $11.000 \mathrm{rpm}$ selama 10 menit. Supernatan yang diperoleh adalah ekstrak antibakteri yang diuji dengan isolat bakteri uji Salmonella sp.

\section{Uji antibakteri dengan Salmonella sp.}

Sebanyak 0,1 ml suspensi Salmonella sp.diinokulasi secara pour plate ke dalam cawan petri steril dan ditambahkan $20 \mathrm{ml}$ media NA. Setelah media padat dibuat sumuran dengan diameter lubang $0,7 \mathrm{~cm}$. Setiap cawan petri berisi tiga sumuran. Pada masing-masing sumuran, dimasukkan zat antibakteri sebanyak 0,1 ml, kemudian diinkubasi dalam inkubator suhu $40^{\circ} \mathrm{C}$ selama 24 jam. Pengaruh $\mathrm{pH}$ terhadap antibakteri dengan Salmonella sp. ditunjukkan dengan adanya zona bening di sekitar sumur. Semakin besar diameter zona Penentuan diameter zona hambat antibakteri yang terbentuk pada setiap sumuran diukur dari tiga sisi yang berbeda, kemudian di rata-rata. 


\section{HASIL DAN PEMBAHASAN}

\section{Potensi antibakteri non asam oleh BAL pada media dengan variasi $\mathrm{pH}$}

Kemampuan isolat B2, B7, dan B8 dari usus itik dalam memproduksi antibakteri ditunjukkan dengan adanya zona bening yang terbentuk disekitar sumur. Zona bening yang terbentuk menunjukkan zona hambat ekstrak antibakteri BAL terhadap Salmonella sp. Potensi antibakteri non asam oleh dengan variasi media $\mathrm{pH} 4-8$ mampu memproduksi antibakteri yang menghambat pertumbuhan bakteri Samonella sp. Setiap isolat B2, B7, dan B8 memeliki kemampuan berbeda beda dalam menghasilkan daya hambat terhadap Salmonella sp. Diameter zona bening terbesar dihasilkan oleh isolat B7 pada pH 6 sebesar 17,2 mm dan B8 sebesar 17,1 mm, kemudian isolat B2 pada $\mathrm{pH} 7$ memiliki diameter zona bening sebesar $16,7 \mathrm{~mm}$, sedangkan diameter zona bening dihasilkan oleh B8 pada pH 4 sebesar 15,1 mm, kemudian isolat B2 pada pH 6 sebesar 12,7 mm dan isolat B7 pada pH 5 sebesar 11,5 mm. Perbedaan diameter zona bening isolat B2, B7 dan B8 dengan variasi $\mathrm{pH}$ media dapat dilihat pada Gambar 1.

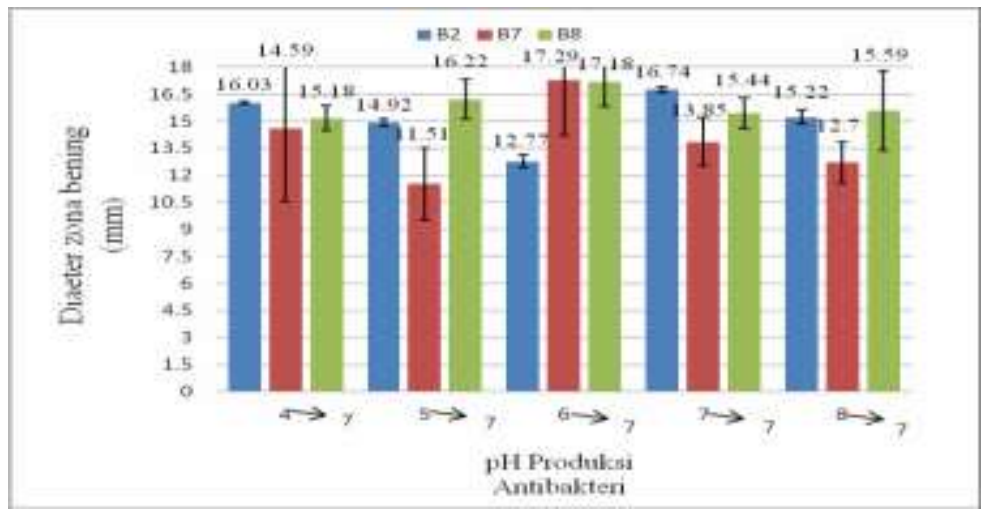

Gambar 1. Perbedaan diameter zona bening isolat B2, B7 dan B8 dengan variasi pH media

Pada media pH 6 dan pH 7 ditunjukkan besarnya daya hambat B2, B7 dan B8 terhadap Salmonella sp. yang dapat dilihat pada (gambar 2), (gambar 3) dan (gambar 4) di bawah ini:

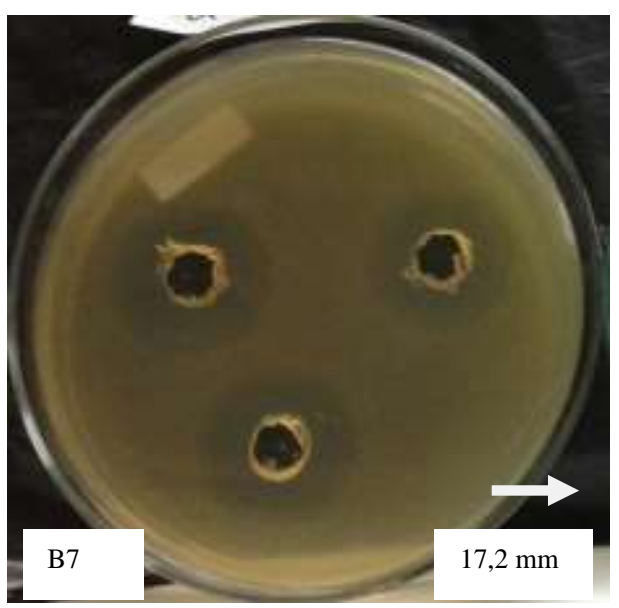

Gambar 2. Diameter zona bening pH 6

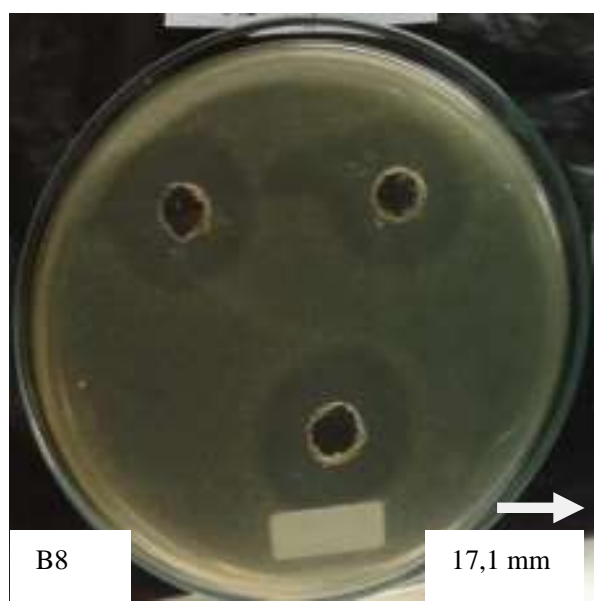

Gambar 3. Diameter zona bening pH 6 


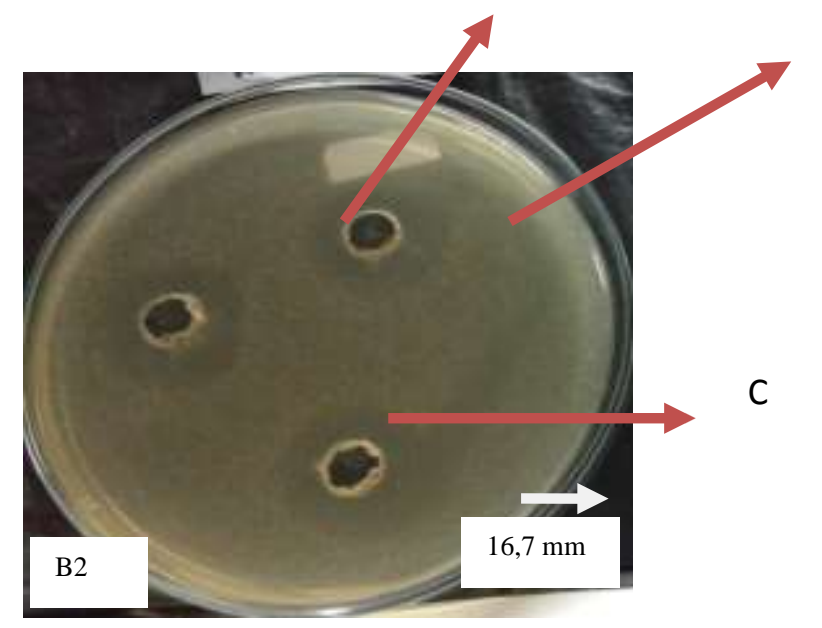

Keterangan Gambar:

A : Zat antibakteri BAL

B: Kultur Salmonella sp. yang tumbuh

C: Zona bening yang terbentuk

Gambar 4. Diameter zona bening pH 7

Potensi antibakteri non asam oleh 3 isolat (B2, B7, dan B8) dengan variasi $\mathrm{pH}$ media untuk produksi antibakteri mampu menghambat Salmonella sp. Kemampuan setiap isolat berbeda-beda (berbeda nyata) dalam menghasilkan diameter hambat zona. Bakteriosin bekerja menghambat pertumbuhan Salmonella $s p$. tanpa pengaruh asam dari perlakuan $\mathrm{pH}$ media. Hasil penelitian menunjukkan bahwa pada pH 6-7 isolat B2, B7,dan B8 menghasilkan zona hambat terbesar sedangkan pada $\mathrm{pH} 4$ isolat B2, B7, B8 menghasilkan zona hambat terkecil untuk produksi antibakteri.

Menurut Andriani dan Kurniawati ( 2007), besarnya nilai pKa, yaitu besarnya molekul yang tidak dapat terdisosiasi dipengaruhi oleh kemampuan antibakteri dari asam organik (asam laktat dan asam asetat). Asam asetat memiliki aktivitas antimikroba yang lebih tinggi dibandingkan asam laktat karena nilai pKa asam asetat lebih besar daripada asam laktat. Andriani dan Kurniawati (2007) bahwa asam laktat dan asam asetat dihasilkan dari metabolit primer memiliki kemampuan sebagai antibakteri dalam menghambat Salmonella sp. Asam organik dari BAL sebagai antibakteri memilki kemampuan dalam menurunkan pH menjadi 3 - 4,5. Hendriani (2009) menyebutkan bahwa hasil metabolit primer dari BAL berfungsi sebagai antibakteri, antara lain senyawa peptida antimikroba yang disebut bakteriosin, asam organik (asam laktat dan asam asetat), dan karbon dioksida $\left(\mathrm{CO}_{2}\right)$. Menurut Mojgani dan Amirnia (2007), pengaruh pH merupakan salah satu faktor penting dalam pertumbuhan dan pembentukan bakteriosin pada bakteri asam laktat. L. casei RN 78 tumbuh baik dan memproduksi bakteriosin secara maksimal pada pH 5 dan 6 dalam media MRS

Bakteri yang hidup pada $\mathrm{pH}>4,5$ akan mati, termasuk bakteri patogen yaitu Salmonella sp.Salmonella sp. membutuhkan pH optimum sebesar 6,5 - 7,5 meskipun memiliki kemampuan hidup pada derajat $\mathrm{pH}$ 4-9. BAL mampu menghasilkan asam organik untuk menurunkan $\mathrm{pH}$ lingkungan yang berfungsi untuk menghambat pertumbuhan Salmonella sp. Menurut Cotter (2003), asam laktat mampu menghambat pertumbuhan bakteri patogen termasuk Salmonella sp. yaitu spesies Gram negtaif dan berbagai tipe bakteri pembusuk. Menurut Mustakin (1993), asam laktat terbentuk dari bakteri asam laktat yang mampu mengubah karbohidrat (glukosa) menjadi asam laktat. Fungsi bakteri dari asam laktat ini menurunkan $\mathrm{pH}$ lingkungan menjadi 3 sampai 4,5 sehingga pertumbuhan bakteri lain termasuk bakteri pembusuk akan terhambat (Rostini, 2007). Pada umunya mikroorganisme dapat tumbuh pada kisaran pH 6-8 (Buckle et al., 1987). Dengan terbentuknya zat antibakteri dan asam maka pertumbuhan bakteri patogen akan dihambat (Rostini, 2007). Menurut Syabana (2007) salah satu aspek penting dalam hal aplikasi bakteri asam laktat dalam proses fermentasi adalah kemampuannya untuk memproduksi bakteriosin. Bakteriosin adalah protein yang dihasilkan oleh 
bakteri asam laktat yang mampu menghambat pertumbuhan berbagai patogen dan bakteri perusak. Asam laktat dapat terbentuk melalui proses fermentasi yang berlangsung dengan adanya aktivitas bakteri asam laktat yaitu Lactobacillus, yang berlangsung secara spontan, dan terjadi secara alamiah dengan memperhatikan kondisi lingkungannya yaitu anaerobik.

\section{KESIMPULAN}

Hasil penelitian menunjukkan bahwa $\mathrm{pH}$ 6-7 bisa digunakan sebagai $\mathrm{pH}$ optimum produksi antibakteri oleh isolat B2, B7, B8 dari usus itik. Isolat B7 menghasilkan daya hambat terbesar yaitu sebesar 17,2 mm terhadap Salmonella sp.

\section{DAFTAR PUSTAKA}

Andriani., D., W. Kurniawati. 2007. Pengaruh Asam Asetat dan Asam Laktat sebagai Antibakteri Terhadap Bakteri Salmonella sp. yang Diisolasi dari Karkas Ayam. J. Seminar Nasional Teknologi Peternakan dan Veteriner 2007: 930-934.

Anggorodi, R., 1984. Ilmu Makanan Ternak Umum. PT. Gramedia, Jakarta.

Buckle, K. A., R. A. Edwards, G. H. Fleet, and M. Wooton. 1987. Ilmu Pangan. Universitas Indonesia Press. Jakarta.

Cotter, P. D., and C. Hill. 2003. Surviving the Acid Test: Responses of Gram positive Bacteria to Low pH. Microbiol. Mol. Biol. Rev. 67 (3): 429-453.

Hendriani, R., T .Rostinawati, S.A.F. Kusuma. 2009. Penelusuran Antibakteri Bakteriosin dari Bakteri Asam Laktat dalam Yoghurt Asal Kabupaten Bandung Barat terhadap Staphylococcus aureus dan Escherichia coli. Laporan Akhir Penelitian Peneliti Muda (LITMUD) UNPAD. Lembaga Penelitian Dan Pengabdian Kepada Masyarakat Universitas Padjadjaran. Jatinangor.

Januarsyah, T. 2007. Kajian aktivitas hambat bakteriosin dari bakteri asam galur SCG 1223. Skripsi. Institut Pertanian Bogor. Bogor

Jawet, Melnik dan Adelberg. 1996. Mikrobiologi Kedokteran. Jakarta.

Langhout, P. 2000. New Additives for broiler chicken. Feed Mix. The International Journal on feed, Nutrition and Technology 9(6):24 - 27.

Mojgani, N. and C. Amirnia. 2007. Kinetics of Growth and bacteriocin production in L. casei RN 78 isolated from a dairy sample in IR Iran. International journal of Dairy science 2(1): 1-12

Sujaya I. N, Ramona Y, Utami D. N. M, Suariani N. L. P, Widarini N. P, Nocianitri K. A, Nursini N. W. 2008. Isolation and characterization of Lactic acid bacteria from Sumbawa mare milk. $J$ Vet 9: 52-59.

Tillman, A. D., Hari H., Soedomo R., Soeharto P., dan Sukato, L.,1989. Ilmu Makanan Ternak Dasar. UGM-Press, Yogyakarta. 